\title{
Atypical cause of lobar collapse
}

\author{
Meera Sunther, ${ }_{1}^{1}$ Gary Ruiz, ${ }^{2}$ Nadia Audi, ${ }^{2}$ Rossa Brugha'
}

1Paediatric Respiratory Medicine, Great Ormond Street Hospital For Children NHS Foundation Trust, London, UK

${ }^{2}$ Paediatric Respiratory Medicine, King's College Hospital NHS Foundation Trust, London, UK

Correspondence to Dr Meera Sunther; m.sunther@nhs.net

Accepted 17 June 2020

\section{DESCRIPTION}

A 6-year-old previously healthy boy presented with a 5-day history of fever, malaise and pharyngitis. His parents brought him to the emergency department due to a new onset of cough and difficulty in breathing. He was fully immunised with no recent travel history or infectious contacts. At presentation his respiratory rate and oxygen saturation were normal. Chest examination revealed reduced air entry over the right upper zone. His chest radiograph (day 7 of illness, figure 1) showed right upper lobe subsegmental consolidation and right paratracheal lymphadenopathy. He was discharged with oral co-amoxiclav, however re-presented after 48 hours with worsening symptoms.

On admission he was feverish $\left(38.5^{\circ} \mathrm{C}\right)$, hypoxic (saturation 91\% breathing room air) and tachypnoeic (respiratory rate 28 breaths/min). Examination demonstrated signs of respiratory distress with bronchial breathing over the right upper zone, pharyngeal congestion, anterior cervical lymphadenopathy but no hepatosplenomegaly. Investigations showed a normal white cell count $\left(5.78 \times 10^{9} / \mathrm{L}\right)$, neutrophil count $\left(3.28 \times 10^{9} / \mathrm{L}\right)$, lymphocyte count $\left(1.58 \times 10^{9} / \mathrm{L}\right)$ and a mildly raised C-reactive protein $(10 \mathrm{mg} / \mathrm{dL})$. A repeat chest radiograph (day 10 of illness, figure 2) demonstrated right upper lobe collapse and consolidation within the left lower lobe. He was referred to a specialist paediatric respiratory team on day 12 of his illness due to persistent fever and respiratory symptoms.

Right upper lobe collapse secondary to extrinsic bronchial obstruction due to lymph node enlargement should prompt exclusion of tuberculosis (TB). However, the clinical presentation is more suggestive of an atypical infection which has not improved with empirical treatment for a presumed typical

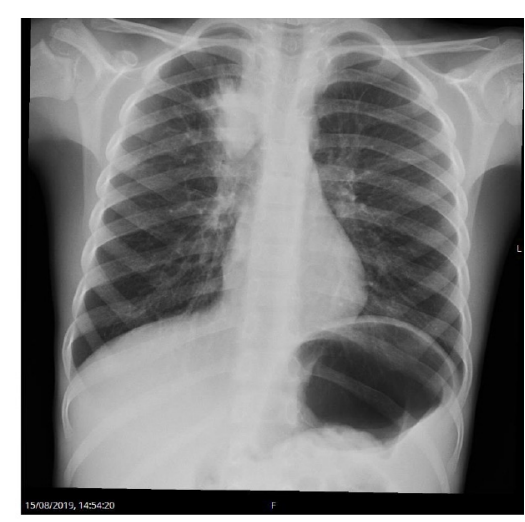

Figure 1 Chest radiograph (day 7 of illness). There is right upper lobe subsegmental consolidation and right paratracheal lymphadenopathy; the lungs are also hyperinflated.

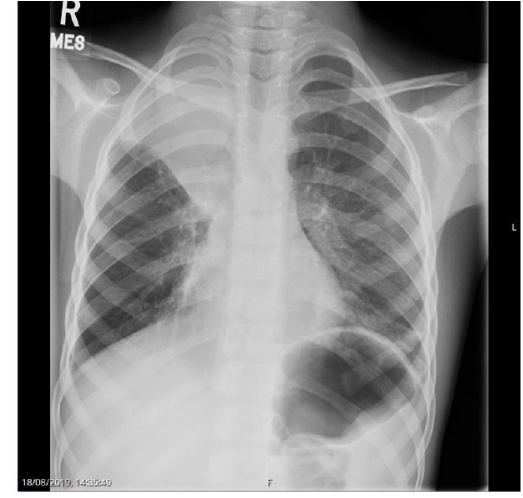

Figure 2 Chest radiograph (day 10 of illness). There is a dense right upper lobe collapse; consolidation is present within the left lower lobe and right middle lobe.

community-acquired pneumonia (CAP). Investigations for TB including Mantoux test, Quantiferon-TB and three early morning gastric aspirates were negative. Nasopharyngeal aspirate for respiratory virus detection by reverse transcription PCR was also negative. As the cough was non-productive, sputum cultures were not sent. Multiplex PCR assay was positive for Mycoplasma pneumoniae from an oropharyngeal swab. This patient showed significant clinical and radiological response to intravenous co-amoxiclav and oral azithromycin after 5 days. Follow-up (8 weeks) chest radiograph showed complete aeration within the right upper lobe.

M. pneumoniae pathogenicity arises from specialised terminal organelles composed of integral membrane proteins (eg, P30) that mediate attachment and gliding motility along the respiratory epithelium. ${ }^{1}$ Mycoplasma lacks a peptidoglycan cell wall, differentiating it from other bacteria and conferring intrinsic resistance to beta-lactam antibiotics that inhibit cell wall synthesis. ${ }^{2}$ Macrolides exhibit activity against Mycoplasma by binding to the 50S ribosomal subunit inhibiting protein synthesis at the chain elongation step.

M. pneumoniae in children hospitalised with CAP is associated with variable radiographic abnormalities. $^{34}$ In a prospective study of 2254 US children ( $<18$ years) hospitalised with CAP, 8\% were M. pneumoniae PCR-positive. ${ }^{4}$ Hilar lymphadenopathy was more common in M. pneumoniae PCR-positive than negative children $(10 \%$ vs $6 \% ; \mathrm{p}=0.02) .{ }^{4}$ There were no reports of lobar or segmental collapse. The most frequent radiographic abnormalities included consolidation (59\%), single lobar infiltrate (32\%) and pleural effusion (26\%). Our case highlights an 'atypical' radiographic presentation of $M$. pneumoniae responsive to both the antimicrobial and anti-inflammatory effects of a macrolide agent. 


\section{Learning points}

- Mycoplasma pneumoniae pneumonia is associated with variable radiographic abnormalities and should be suspected in those with a compatible clinical syndrome.

- An antibiotic with activity against M. pneumoniae (eg, a macrolide) should be considered in children of all ages who do not respond to treatment for a presumed typical community-acquired pneumonia .

Twitter Rossa Brugha @_rossa_

Contributors MS wrote the manuscript under the guidance and supervision of GR and RB.
Funding The authors have not declared a specific grant for this research from any funding agency in the public, commercial or not-for-profit sectors.

Competing interests None declared.

Patient consent for publication Parental/guardian consent obtained.

Provenance and peer review Not commissioned; externally peer reviewed.

\section{REFERENCES}

1 Chang $\mathrm{H}-\mathrm{Y}$, Prince $\mathrm{OA}$, Sheppard ES, et al. Processing is required for a fully functional protein $\mathrm{p30}$ in Mycoplasma pneumoniae gliding and cytadherence. J Bacteriol 2011:193:5841-6.

2 Shah SS. Mycoplasma pneumoniae as a cause of community-acquired pneumonia in children. Clin Infect Dis 2019;68:13.

3 Gordon 0, Oster Y, Michael-Gayego A, et al. The clinical presentation of pediatric Mycoplasma pneumoniae Infections-A single center cohort. Pediatr Infect Dis J 2019:38:698-705.

4 Kutty PK, Jain S, Taylor TH, et al. Mycoplasma pneumoniae among children hospitalized with community-acquired pneumonia. Clin Infect Dis 2019;68:5.

Copyright 2021 BMJ Publishing Group. All rights reserved. For permission to reuse any of this content visit https://www.bmj.com/company/products-services/rights-and-licensing/permissions/

BMJ Case Report Fellows may re-use this article for personal use and teaching without any further permission.

Become a Fellow of BMJ Case Reports today and you can:

- Submit as many cases as you like

- Enjoy fast sympathetic peer review and rapid publication of accepted articles

- Access all the published articles

- Re-use any of the published material for personal use and teaching without further permission

\section{Customer Service}

If you have any further queries about your subscription, please contact our customer services team on +44 (0) 2071111105 or via email at support@bmj.com.

Visit casereports.bmj.com for more articles like this and to become a Fellow 